\title{
Cyber Resilience of Small and Medium Enterprises in Semarang City
}

\author{
${ }^{1}$ IKA RISWANTI PUTRANTI, 2 RENI WINDIANI, ${ }^{3}$ NADIA FARABI, \\ ${ }^{4}$ ANITA AMALIYAH, ${ }^{5}$ MOHAMMAD ROSYIDIN \\ ${ }^{12345}$ Fakultas IImu Sosial dan Ilmu Politik Universitas Diponegoro, Semarang, Indonesia \\ Correspondence author: ikariswantiputranti@lecturer.undip.ac.id
}

\begin{abstract}
This paper seeks to examine cyber resilience of small and medium enterprises of handicraft under the scheme of Semarang City smart economy platform. It finds out whether the enterprises well prepared for the cyber system and has the ability to employ the facilities provided by the government and whether the government provided adequate governance and legal framework to provide secure environment that supports the development of cyber resilience in smart public services. This study uses a qualitative descriptive method which employs both in-depth interviews for the primary data and statute approach for the secondary data on analysis of governance and legal frameworks provided by the government to support cyber resilience and how the opportunities and challenges could be addressed to establish robust cyber resilience. The results of the study show that the concept of cyber resilience in Smart City for SMEs with specific references to the city of Semarang is still poorly understood by business people and stakeholders in the field. Moreover, smart city as a place of various aspects such as economy hasn't had clear legal framework regarding smart city at the national level.
\end{abstract}

Keywords: Cyber Resilience, SMEs, Smart City

\section{Introduction}

The Smart City concept has become one of the spearheads in encouraging a revolution towards public services that are more transparent, accountable, fast, and affordable for all levels of society. According to some sources, smart city is a city area that has integrated information and communication technology in daily governance to enhance efficiency, improve public services, and improving the welfare of citizens. In general, smart city in Indonesia has experienced several obstacles such as inadequate supporting infrastructure, local government readiness in terms of human resources and regulations and extra budget, and the condition of people who have not been able to utilize technology features in smart city optimally (Setiaji, 2018). Nowadays, smart city services do not only cover administrative matters such as population affairs, but also services in business sectors which are referred to as smart economy.
The smart economy is one of the elements of smart city services that can be used to support economic and business activities assisted by technopreneur information technology (Smart Cities Berkeley, 2019). However, the definition of smart city is not agreed upon by experts. The concept of smart economy brings together a number of elements such as innovative sustainable and eco-economy approaches, high productivity economy, global economic growth, healthy business competition, economic progress, economic prosperity, innovation, sustainable employment, and digital economy. The development of the concept of "smart economy" is intended to encourage the growth of entrepreneurship for economic growth that is smart, sustainable and inclusive by utilizing creative, innovative potentials, skills in using information technology, environmentally friendly production, high levels of social welfare, and the balance of interests of all stakeholders (Apostol et 
al., n.d.; Pavlivna Galperina et al., 2016) nonrenewable resources, desertification and unsustainable emissions. All these actions seem to restrict economy and its capacity of contributing to the reduction of inequalities. What remains central and problematic is the attempt to satisfy the needs of the present without prejudicing the future generation's capacity of equally covering their needs (Brundtland Commission 1987.

In smart economy, Small and Medium Enterprises (SMEs) are one of the main backbones. The economic activities of SMEs cannot be separated from the condition and structure of a city (Amrullah and Utami, 2018). Therefore, according to Article 1 paragraph 10 of Law Number 20 of 2008, the regional government is one of the stakeholders who has an obligation in developing SMEs. SMEs refers to the efforts made by the government, regional government, business, and the community (Merina, 2016) to empower and improve the competitiveness of medium and micro enterprises through the provision of facilities, guidance, and assistance. Therefore, features and facilities in smart city are designed in such a way to help the development of SMEs.

As one of the dynamic economic sectors and able to survive in various economic situations such as the 1997 crisis, the potential of Indonesian SMEs is very high. According to Bappenas (Indonesian National Development Planning Agency) data in 2015, SMEs in Indonesia were estimated to reach 60.7 million units, of which $98.73 \%$ were micro-scale businesses. Then in 2015, the number of workers in SMEs reached 132.3 million even though $88.6 \%$ of them were still informal workers in micro-scale businesses. In terms of exports and investment, SMEs have a strategic role where non-oil and gas exports of SMEs reach 192.5 trillion rupiahs. In this case, medium-sized businesses have the largest export contribution of 76.6 percent, and micro-enterprises are still limited to 7.9 percent. The increasing openness of trade flows between goods and services among countries as a consequence of the free market has encouraged an increase in the volume of economic activity between individuals and economic operators among countries. This also has an impact on increasing crossborder connectivity, and increasingly intense interactions between the components of the world community, thereby increasing the dependence of the economic and trade sectors on the cyber world. Economic growth, innovation, information exchange and science bring many positive benefits to the formation of a literary society about information technology. However, security risks also continue to increase from year to year.

Developing SMEs networking is one of the crucial factors in capturing business opportunities. Development of networking includes professional or business networks such as relationships between companies, buyers, suppliers, and competitors (Bappenas, 2016a).

According to the Indonesian Central Statistics Agency, there were 3.79 million SMEs who had used digital technology or e-commerce businesses. Most SMEs use the main market place platforms in Indonesia, such as Blibli, Tokopedia, Lazada, Bukalapak, Shopee, and Blanja.com (Walfajri and Narita, 2018). This was reinforced by data from the Ministry of Cooperatives and Small and Medium Enterprises which noted that as many as 3.79 million SMEs had used online platforms to market their products with the number around 8 percent of the total SME actors in Indonesia (Kementerian Komunikasi dan Informatika, 2018).

The handicraft industry is one of the business sectors of the SMEs that is prioritized to be developed because it produces high value-added products and absorbs many labours. The handicraft industry continues to grow by producing various superior crafts, including those made from wood, metal, leather, glass, ceramics and textiles. Data from the Ministry of Industry noted that the export value of national craft products in 2017 reached USD776 million, which was increased compared to 2016 of USD747 million. Meanwhile, the number of handicraft industries in Indonesia was more than 700 thousand business units with employment of 1.32 million people (Siaran Pres Kemenperin RI, 2018). Handicraft products are some of SME's superior products that have a good market in Europe and America to date. The use of cyberspace and information technology channel is effective and affordable but yet can expand market network coverage and supply raw material needed (Berdesa, 2016; Stefanie, 2018).

Therefore, with its potential, the ability to increase SMEs, especially in the handicraft sector, needs to be developed. The government made various efforts, one of which was the Digital Economy and Smart City Workshop which aimed to provide knowledge 
to SMEs about e-commerce. SMEs need to be given an understanding and knowledge of exposure to various risks in the digital economy such as financial stability, payment systems, cybersecurity, transaction integrity and security, and consumer protection (Septiadarma and Triwidodo, 2017).

One of the risk exposures associated with cybersecurity is that SMEs are very vulnerable to cybercrime and cyber-attacks. Cybersecurity and resilience, where large companies are increasingly being sophisticated and constantly updated make it difficult for perpetrators to carry out attacks. In general, it is found that SME owners and employees do not have sufficient knowledge and abilities related to cyber resilience. Why does it choose cyber resilience and not cybersecurity? It is because security is not enough; it must also be resilient by having dynamic capabilities and strategies in responding to every attack on the system to be able to maintain the sustainability of its business and make its resilience system one of the comparative advantages in fair business competitions.

In general, security is defined as a reduction in the risk of important infrastructure through certain means or cybersecurity measures against intruders, attacks, or the effects of natural or man-made disasters (Putranti, 2015). The United States Department of Defence defines resilience as the ability to be ready for everything and can immediately adapt to changes and survive and be able to recover quickly from damage. Most people think both cybersecurity and cyber resilience are the same things. The main purpose of cyber resilience is to strengthen the collective ability to overtake attacks, to detect temporary attacks, react to attacks, to reduce the impact of attacks, to track the origin of attacks, and quickly restore their functions, and at the same time taking lessons from cases that occur.

The development of SMEs in Indonesia is divided into 4 criteria. The SMEs handicrafts being studied are registered in the smart economy site of the Semarang smart city. SMEs that have adequate cyber resilience can make it one of the supporting factors in building a sustainable business so that they can build trust from various parties to be able to support the development of their business. The 2015 Focus Group on the Smart Sustainable Cities International Telecommunication Union in its Technical Report states that cybersecurity, data protection, and cyber resilience are the backbone of sustainable smart city development.

Yudi Prayudi, Head of the Center for Digital Forensics Studies, Islamic University of Indonesia, revealed that the NationWide insurance company had surveyed 500 companies at the SME level, showing that 8 out of 10 SME companies did not have computer security planning systems including mitigation concepts, which make them prone to becoming victims of cybercrime. Risk mitigation here goes into what is called cyber resilience (Koran Sindo, 2016). Some of the threats of cybercrime and cyberattacks against SMEs include deliberate virus spread, business site takeovers, bank account takeovers (Bisnis UKM, 2013), takeover of customer and supplier data, account takeover, piracy of intellectual property rights, and legal risk. In addition, data from Symantec in 2015 showed $43 \%$ of cybercrime attacks aimed at the SMEs business group. Generally, large/ multinational companies, banks, government, law enforcement agencies, and universities are the main targets of criminals in cyberspace. However, with the increasingly widespread SMEs business utilizing cyberspace and information technology as their business platforms, the focus of criminals began to target them. As a result of the weak cybersecurity of SMEs, it can lead to potential business losses due to loss of business reputation and consumer trust, legal disputes that may arise due to third party losses, high cost of recovery, and even loss of company value and assets (Prayudi, 2018).

Semarang City is one of the big cities in Indonesia which has since 2013 built Smart City to support the improvement of public services and community participation in economic development. One sector that is able to develop to answer the challenges of the development of economic digitalization is the sector of SMEs, where handicraft SMEs are one of its superior (Rachmi Hayati, 2018; Jateng Pos, 2018; Rizkia and Mahardy, 2018; Tribun Jateng, 2018). However, according to Dinas UMKM (SMEs office) Semarang City, SME's handicraft has only $2 \%$ out of total products. Thus, it is clear that the challenge lies on maximizing digital approach in disruptive economy (see figure 1).

Currently, the total number of SME business in Semarang City is 11,692 units with an annual growth rate of $1.97 \%$ (Sismanto, 2016). Then, according to information from a field study conducted by researchers. There 
were only 2000 active SMEs in the business, based on the monitoring of the Semarang City Local Agency of Cooperative and Micro Business. Thus, there are 43 craft SMEs listed in the Smart City of Semarang City (Pemerintah Kota Semarang, 2016).

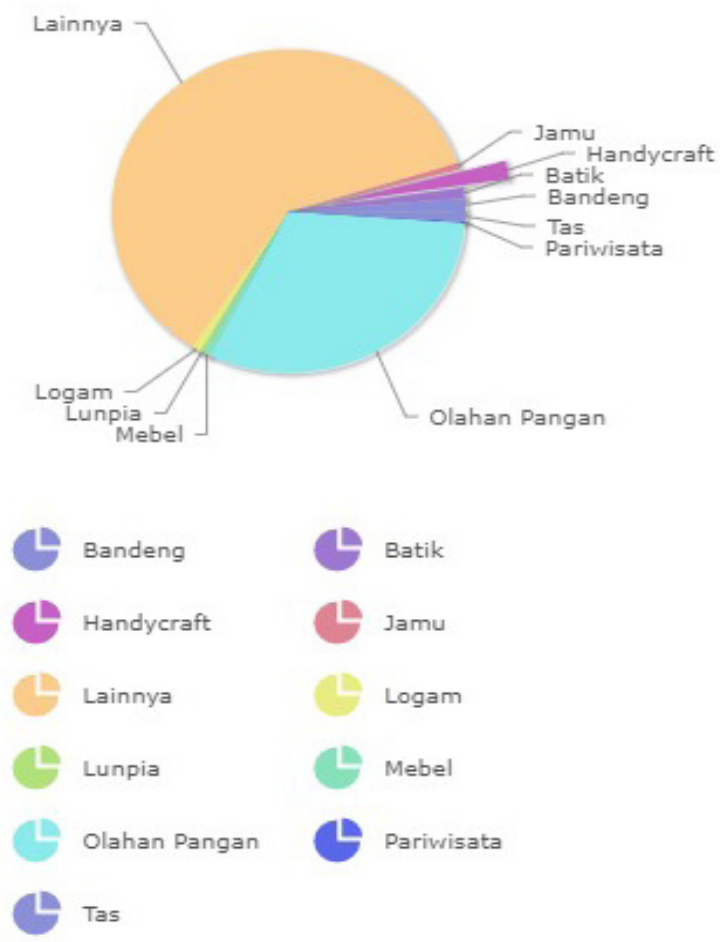

Figure 1. UMKM Cluster Products in Semarang City

The movement from traditional to online needs a comprehensive structure in which cyber resilience is the answer. It is because Smart City is an international concept echoed by the Indonesian government that made many cities compete in executing the project without understanding it completely. Semarang is one of the cities that has been implemented smart city concept since 2013 besides other big cities such as Surabaya, Bandung and Jakarta; and one of the goals under smart economy components by Semarang government is their business process.

SMEs became a priority concern as the government expects the rise of income and social welfare by employing and marketing the SMEs industry into the website and applications by way of creating a specific identification tool so that the government can control them as well. The growth of SMEs in Semarang almost reaches 2000 businesses each year but we could not find the right data registered which the government

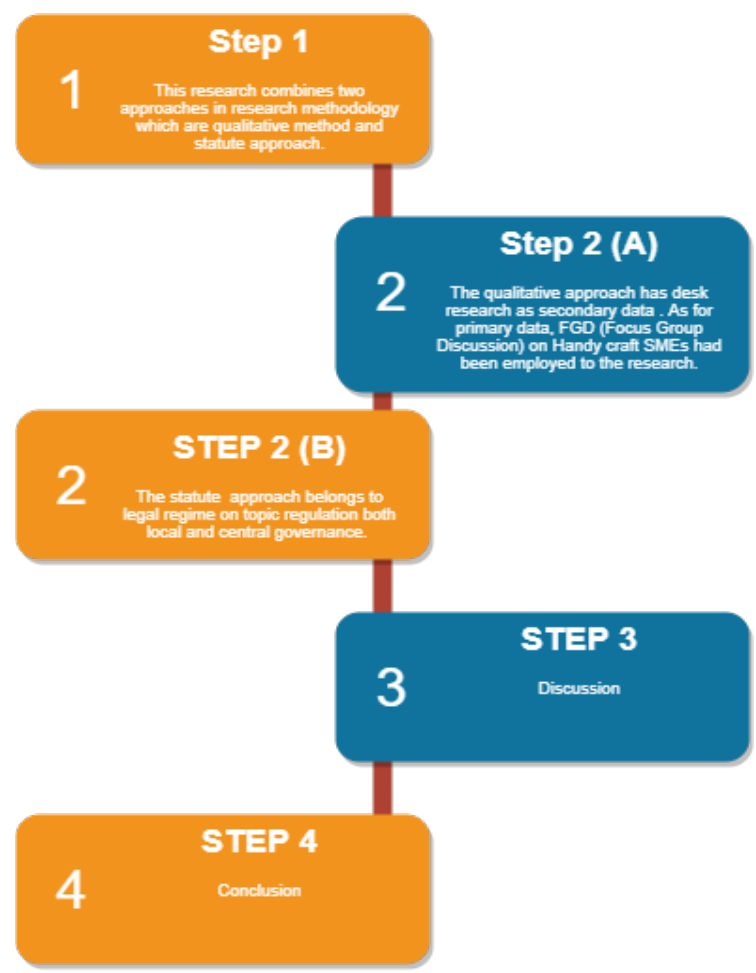

Figure 2. Research Flow Chart

should had. Besides the website of Semarang smart city, the government also initiated an application to facilitate the SMEs registration called I-Jusmelon (Arifin, 2018). The website is barely for registration purposes only without allowing public to see the actual SME's registered by this application. With all those findings, the threat from cyber world is more complex and makes those SMEs more vulnerable without the facilitation from the government. Those SMEs join the cyber world of industries without government's supervision. For example, more than 3000 SMEs use accounting applications provides by private parties to ease their business which the government could initiate and provide. Therefore, as described above, this paper will analyze qualitatively and descriptively the cyber resilience of SMEs Handicraft in Semarang City, Central Java, and the extent to which the Semarang city government with smart city platforms is able to prepare adequate governance and legal framework to encourage SMEs building cyber resilience.

\section{Research Methodology}

This research is both qualitative research and legal approach. This paper analyzes qualitatively descriptively the cyber resilience of SMEs Handicraft in Semarang City, Central 
Java. Qualitative research properly seeks answers to questions by examining various social settings and the individuals in these settings. For the most part, the approach resembles the theory-before-research model. But it could also be drawn as the researchbefore-theory model: Idea -> Design -» Data Collection -» Theory ->Analysis -» Findings (see figure 2).

The data used as materials of this research are divided into two: primary and secondary data. Primary data is the highlight findings-based on SMEs FGD's. Meanwhile, secondary data is supporting data in the form of data of subject of research, namely documents related to legal implementation such as laws and regulations relating to the topic, and other policies.

\section{Results and Discussions}

\section{Seizing Opportunities and Address- ing Challenge}

From the results of field research, there were 43 craft SMEs who were surveyed based on data available in smart city in Semarang City. The survey questions are intended to map the extent to which cyber resilience is understood by SMEs handicrafts in the city of Semarang. Survey questions are divided into 4 main points. The first point is general questions related to cyber resilience which aims to see the extent to which SMEs handicrafts know and understand the concept of cyber resilience in their business process. In this first point, there are 9 questions interrelated with each other such as the use of electronic devices, types of software or interfaces, cyber-attacks and their types, and actions taken in handling cyber-attacks. At this first point, 9 SMEs out of 43 handicraft SMEs were considered know and understand cybersecurity.

The second point questions about cyber resilience-related to company management. In this context, it concerns human resources and governance of the use of information technology in managing business, such as who runs and manages cyber facilities in the company, how employees access the existing facilities, update the technology, back up data, secure passwords and company data, and awareness of intellectual property rights in cyberspace. At this second point, only 6 of 43 craft SMEs respondents registered in the Semarang smart city understand and apply the concept of cyber resilience in the business management processes.
The third point questions about cyber resilience related to the field of corporate marketing. In this point, the questions raised concerning the transaction management system, the use of internet banking or fintech, the media used for marketing, the guarantee of protection of subscription data, problems in transactions with customers and third parties, and settlement of disputes in transactions with customers and third parties. At the point of management, only 6 of the 43 craft SMEs respondents registered in the Semarang smart city understood and applied the cyber resilience concept.

The fourth point questions about cyber resilience in the field of production. In this point, the question is more focused on the knowledge of SMEs about cybersecurity in the production chain. At the last point related to the production, there were 8 of $43 \mathrm{craft}$ SMEs respondents registered in the Semarang smart city who understood and applied the cyber resilience concept.

Based on the in-depth interviews conducted with stakeholders such as the Local Agency of Cooperatives and Micro-Business, it was found that training had been carried out several times for SMEs business actors in general which included SMEs in handicraft. However, no training has been conducted specifically related to fostering SMEs in cyber resilience. The training carried out so far is only related to the use of cyber technology to support the business continuity of SMEs.

From the results of the mapping and the data obtained from the field, further confirmation was made with the relevant parties and stakeholders by data triangulation through Focus Group Discussion (FGD). In the FGD, there were some interesting findings related to SMEs Handicraft in the city of Semarang where the data presented in smart city was out of sync with existing data from the Local Agency of Cooperative and Micro Business of City of Semarang. Some SMEs in Semarang City who are registered in smart city have closed or switched business, but the existing data is not updated properly. These circumstances could undermine public trust to the smart city system. Data that is out of sync and not properly verified in a system is also a security hole that can be exploited by perpetrators of crime and can cause public confusion in accessing information. In the digital economy era where opportunities and challenges arise, cyber resilience is one of the important pillars that must be built to be 
able to develop SMEs capable of competing in highly competitive digital space vulnerable to cybercrime.

\section{Legal Outlook: Governance and Reg- ulatory Frameworks for Smart City Cyber Resilience}

The issue of cyber resilience in smart city is not only related to aspects of governance technically but also concerning aspects of politics, social society, bureaucracy, leadership, and the private sector. Decisionmakers and bureaucracy must have a vision in line with the development of cyber resilience development because a temporary project without any blueprint will certainly have no resilience and is vulnerable in anticipating future attacks. Through the right processes, collaboration among various stakeholders and good governance, technology can provide real solutions to problems related to cyber security, information protection, and system resilience. In the context of cyber resilience development, it should not be out of the national cyber security strategy guidelines compiled by the National Cyber and Crypto Agency. The development of cyber resilience has two dimensions that must be applied to ensure that the system built will be used to support sustainable national development.

The government responds to the existing developments by establishing Presidential Regulation Number 53 of 2017 concerning National Cyber and Crypto Agency which amended by Presidential Regulation Number 133 of 2017 concerning establishment of the National Cyber and Crypto Agency (BSSN), where BSSN has the task of implementing cyber security effectively and efficiently by utilizing, develop and consolidate all elements related to national cyber security. The establishment of BSSN aims to create a strategic cyber environment and the implementation of safe, reliable electronic systems; promote and grow the digital economy by increasing competitiveness and cyber innovation; and building awareness and sensitivity to resilience and national security in cyber space. BSSN composes the Indonesian Cyber Security Strategy as a joint reference for all national cyber security stakeholders in developing cyber security policies in their respective agencies. The national cyber security strategy is prepared in line with the basic values of the life of the nation and state, namely Sovereignty, Independence, Security, Togetherness, and Adaptiveness (Badan Siber dan Sandi Negara, 2018).
The vision of Indonesia's cyber security strategy is to build and maintain national cyber security by synergizing various stakeholders to participate in realizing national security and enhancing national economic growth. The strategic objectives of Indonesia's Cyber Security Strategy are the achievement of cyber resilience, security of public services, enforcement of cyber law, and culture of cyber security in the digital economy. The Indonesian Information Security Strategy is expected to be one of the foundations of world trust to Indonesia in various international cyber security forums. Indonesia's Cyber Security Strategy aimed to contribute to world peace and security (Badan Siber dan Sandi Negara, 2018).

Until now, the government will only regulate regulations, standardization, strategies, and cyber security management. This to ensure the development of the internet of things (IoT) in Indonesia will run safely because the 2017 Global Cyber security Index (GCI) stated that Indonesia was in the $69^{\text {th }}$ position of the world with a value of 0.424 , meaning Indonesian cyber security is still weak (Sindo News, 2019). On the other hand, the Information and Electronic Transaction Law is still considered inadequate in managing cyber resilience (Tirto.id, 2019). The weakness of the existing regulatory system at the national level affects the absence of a legal framework for local governments to enact a local regulation regarding cyber resilience.

The most crucial thing is that there has been no clear legal framework regarding smart city at the national level, either in the form of laws or government regulations. Until now, the referral of local government in applying and developing smart city at the local level only refers to the Law No. 23 of 2014 concerning Local Government which stated in the Chapter XXI entitled Local Government Innovation (articles 386 to 390). Another reference is Law Number 14 of 2008 concerning Public Information Openness that requires local governments to implement the principle of transparency. The need for regional regulations on smart city development is an urgent matter as stated by the Minister of Communication and Information Technology (Menkominfo) Rudiantara (Kementerian Komunikasi dan Informatika, 2019). The absence of a legal framework of smart city has also begun to attract the attention of local leaders and bureaucrats due to difficulties in facing existing developments because if this is not immediately anticipated the impact 
of Smart City will be disrupted (Pemerintah Provinsi Jawa Barat, 2016). In this regard, the disturbance on smart city will also disrupt the cyber resilience of the city. In 2017, the Ministry of Home Affairs initiated a national regulation and a comprehensive smart city development guide. The national regulation in the form of presidential regulation will regulate the smart city norms, systems, procedures and criteria. The regulation will be formulated by a team that involves the Ministry of State Apparatus and Bureaucratic Reform, Ministry of Communication and Information, Ministry of National Development Planning/National Development Planning Agency, and Ministry of Home Affairs (INDOPOS, 2017).

\section{Employing Cyber Space for SMEs}

The world has changed because of the rapid development of technology. Back then, when you want to buy unavailable products in your city, you have to go to a big city to get what you need, and now it has changed; you can almost buy everything because of IoT and mobile technology. The conventional methods are replaced with modern ways: cash into cashless, tickets into e-tickets, etc. Also, when you feel lazy and are reluctant to go outside, you simply have to order your favorite food through an app, or you quit buying newspapers because you can read it online with many sources on your cellphone. It is because the modern way is much more simple, efficient, fast, and effective. Those are small things that everyone can do with IoT and mobile technology. The internet users in Indonesia has reached 132,7 million and this number continuously growing; it shows that half of Indonesia's population use internet in their daily life (Wahid, 2017).

Today, because of the IoT and mobile technology, the transaction or direct marketing activities are conducted not only through website, but also via social media accounts such as Instagram, Facebook or even a mobile communication app (WhatsApp) which proven to save time and place. The seller does not need to have a large stall to peddle their merchandise and so do the customers; they even can make orders at home, at working space while do their things (Yasa, 2018). Moreover, sellers and their customers can connect, and the sellers can maintain customer's loyalty rather easier than by traditional marketing (Wahid, 2017).

The digital momentum also impacts on economical perspective; 1700 digital companies are built, the revenue from e-commerce increases, cashless societies grows, e-payment continuous to grow but those big impact haven't reached SMEs in Indonesia yet (Kinda and Yan, 2018). The record says only $5 \%$ of the total SMEs utilize the great digital power (Wahid, 2017) and now government encourages SMEs to go digital and get involved with the hype (Hypernet, 2018). Supporting SMEs became an annual important program by the Indonesia's government because the existence of SMEs has a significant role in regional and state economic development, such as their position as major player in the economic markets and the largest employment providers (Putra, 2016)there are about 57.8 million actors of MSMEs in Indonesia.

In 2017 and the next few years it is estimated that the number of MSME perpetrators will continue to grow. MSMEs have an important and strategic role in national economic development. In addition to its role in economic growth and employment, MSMEs also play a role in distributing development outcomes. So far, MSME has contributed 57,60\% Gross Domestic Product (PBD. Another contribution from SMEs in developing the national economy is their share in the GDP (Gross Domestic Product) that have reached $57.6 \%$ with an average growth of $6.7 \%$ (Bappenas, 2016b). Even the current President of Indonesia, Joko Widodo, emphasizes the important role of SMEs in Indonesia 4.0 plan (Mediatama, 2018). In business industry, it is very essential to adapt to market evolution and its changing demand. When everything goes online and digitalize, the ability to utilize and evolve are matters for transforming any business, especially SMEs. The use of internet improves business performance and profits (Eka, 2018). Furthermore, the use of internet as a marketing tool can cut several costs such as market advertisement since it is cross-border and is not bound by standard rules (Yuliana, 2004).

The increase of sophistication technology employed in SMEs does not only occurs in Indonesia, but also in many countries, such as UK, Denmark, many EU's countries (European Comission, 2017), and Asian countries such as China. The growth of Ali Baba (e-commerce) is one of the examples of large enterprises use some type of big data sources, showing that data-driven business models are becoming a reality accessible to every entrepreneur (Boyes, Isbell, Norris, \& Watson, 2014). 
The unicorn companies from Indonesia such as Traveloka, Bukalapak, and GoJek act the same as other large enterprises (Iriani, 2018): they lead the industry to gain needed target or just developing trends in crowds so that the business can enlarge and utilize other enterprises and SMEs.

The findings in this research showed the similarities of SME's challenges and opportunities around the world. In Malaysia and Turkey, there are three major problems covers the growth of SME's: (a) financial assistance; (b) knowledge-based economy; and (c) marketing assistance (Razak, Abdullah, \& Ersoy, 2018). By adding IoT, SMEs can provide continuity, easy access, productivity, and innovations through collaboration (Carias, 2018). Cyber resilience provides SMEs and citizens protective knowledge to improve their opportunities as a competitive advantage in the digital robust market.

\section{Conclusions}

Based on the discussion and results, there are several findings in this research. First, the concept of cyber resilience in Smart City for SMEs with specific references to the city of Semarang is still poorly understood by business people and stakeholders in the field. This causes the implementation of cybersecurity for their business activities only reaches the stage of responding to attacks but has not yet at the stage of cybersecurity which is important to maintain the sustainability of business. Second, in the context of smart economy, the SMEs' security is still vulnerable to cyber-attacks so that it requires serious attention, especially from existing stakeholders. One of the most important factors is the lack of a clear understanding of the concept of cyber resilience.

Third, there has been no clear legal framework regarding smart city at the national level, whether in the form of laws or government regulations. Until now, the referral of the local government in applying and developing smart city in the local level only refers to Law No. 23 of 2014 concerning Local Government, where it can be found in the Chapter XXI entitled Local Government Innovation (Articles 386 to 390).

Moreover, it is necessary to have a blueprint for cyber resilience models in smart city so that it can be used as a guide for actors in carrying out their functions and duties to build resilience in the cyber world. The remaining factors such as lack of understanding of the importance of cyber resilience in the smart economy become a major issue that extends beyond the limits of the analysis and is left for future research.

\section{Acknowledgment:}

This research is funded by Lembaga Penelitian dan Pengabdian Kepada Masyarakat (Research Institutions and Community Service) Universitas Diponegoro 2018.

\section{References}

Amrullah, A. and Utami, E. (2018). 'Perancangan Sistem Informasi Pada Smart UMKM dalam Mendukung Sleman Smart Regency', Konferensi Nasional Sistem Informasi (KNSI) 2018. Retrieved January 21, 2019 from http://jurnal. atmaluhur.ac.id/index.php/knsi2018/ article/view/341/266

Apostol, D., Bălăceanu, C. and Constantinescu, E. M. (no date) Smart-Economy ConceptFacts and Perspectives. Retrieved January 21, 2019 from http://www.ipe.ro/RePEc/ WorkingPapers/wpconf141113.pdf

Arifin, M. Z. (2018). Litani Minta Pelaku UMKM Kota Semarang Daftarkan Usahanya di I-juz Melon-Tribun Jateng. Retrieved November 16, 2018, from http://jateng. tribunnews.com/2018/07/06/litani-mintapelaku-umkm-kota-semarang-daftarkanusahanya-di-i-juz-melon

Badan Siber dan Sandi Negara (2018). Strategi Keamanan Siber Nasional Retrieved January 25, 2019 from ://bssn.go.id/ strategi-keamanan-siber-nasional/

Bappenas (2016). Penguatan UMKM untuk Pertumbuhan Ekonomi yang Berkualitas. Jakarta. Retrieved January 21, 2019 from https://www.bappenas. go.id/files/8014/8116/6753/Warta_ KUMKM_2016_Vol_5_No_1.pdf

Bappenas (2016). Penguatan UMKM untuk Pertumbuhan Ekonomi yang Berkualitas. Warta KUMKM, p.5.

Berdesa (2016). Produk Kerajinan Tangan UMKM Sangat Diminati di Luar Negeri. Retrieved January 22, 2019 from http:// www.berdesa.com/produk-kerajinantangan-umkm-sangat-diminati-di-luarnegeri/

Bisnis UKM (2013). Cara Menghindari Cyber Crime Bagi UMKM. Retrieved January 21, 2019 from https://bisnisukm.com/caramenghindari-cyber-crime-bagi-umkm. html

Boyes, H. A., Isbell, R., Norris, P., \& Watson, T. (2014). Enabling intelligent cities through 
cyber security of building information and building systems. In IET Seminar Digest. https://doi.org/10.1049/ic.2014.0046

Eka, R. (2018). Lanskap E-commerce di Indonesia dari Perspektif Konsumen. Retrieved November 13, 2018, from https://dailysocial.id/post/e-ecommercedi-indonesia-2018

European Comission (2017). Integration of Digital Technology: Europe's Digital Progress Report, 1-7.

J. F. Carias, L. Labaka, J. M. Sarriegi and J. Hernantes, "An Approach to the Modeling of Cyber Resilience Management," 2018 Global Internet of Things Summit (GIoTS), Bilbao, 2018, pp. 1-6, doi: 10.1109/ GIOTS.2018.8534579.

Hayati, R. (2018). Kembangkan Smart City, Semarang Siap Bersaing dengan Kota Lain di Dunia - Tribun Jateng. Retrieved November 16, 2018, from http:// jateng.tribunnews.com/2018/10/10/ kembangkansmart-city-semarang-siapbersaing-dengan-kota-lain-di-dunia

Hypernet (2018). Alasan UKM Perlu Melakukan Digitalisasi Untuk Dongkrak Ekonomi. Retrieved from https://hypernet. co.id/2018/05/14/alasan-ukm-perlumelakukan-digitalisasi-untuk-dongkrakekonomi/

INDOPOS (2017). Retrieved June 13, 2019 from https://www.indopos.co.id/

Iriani, T. Y. (2018). Analisis Dampak Layanan Go-Food terhadap Omzet Penjualan Rumah Makan di Kota Bandung Tita Yulia Iriani.

Jateng Pos (2018) Semarang Smart City Makin Inovatif - Jateng Pos. Retrieved January 22, 2019 from http://jatengpos.co.id/ semarang-smart-city-makin-inovatif/

Kementerian Komunikasi dan Informatika (2018). Kemenkop UKM: 3,79 Juta UMKM Sudah Go Online. Retrieved January 22, 2019 from https://www.kominfo.go.id/ content/detail/11526/kemenkop-ukm379-juta-umkm-sudah-go-online/0/ sorotan_media.

Kementerian Komunikasi dan Informatika. (2019). Menkominfo untuk Bangun Kota Cerdas Dibutuhkan Perda. Retrieved from https://kominfo.go.id/index.php/content/ detail/4609/Menkominfo\%3A+Untuk+Ba ngun+Kota+Menjadi+Cerdas+Dibutuhka n+Perda/0/berita_satker

Kinda, T., \& Yan, T. (2018). Indonesia yang Cerdas Digital (Digital-Savvy). Jakarta.

Koran Sindo (2016). Pemerintah Perlu Beri Pendampingan UKM : Okezone Economy. Retrieved January 21, 2019 from https://economy.okezone.com/ read/2016/05/23/320/1395588/ pemerintah-perlu-beri-pendampinganukm.

Mediatama, G. (2018, April 4). Jokowi minta industri 4.0 menyasar sektor UMKM. Retrieved November 16, 2018, from http://nasional.kontan.co.id/news/ jokowi-minta-industri-40-menyasarsektor-umkm

Merina, N. (2016). Apa Itu UKM \& UMKM ? perbedaannya dan definisi UKM, UMKM \& Startup. Retrieved January 21, 2019 from http://goukm.id/apa-itu-ukm-umkmstartup/

Pavlivna Galperina, L., Tymofiyivna Girenko, A. and Petrivna Mazurenko, V. (2016) 'International Journal of Economics and Financial Issues The Concept of Smart Economy as the Basis for Sustainable Development of Ukraine', International Journal of Economics and Financial Issues, 6(S8), pp. 307-314. Retrieved January 21, 2019 from http:www.econjournals. com.

Pemerintah Kota Semarang (2016). Usaha Kecil Menengah. Retrieved August 14, 2019 from http://smartcity.semarangkota. go.id/UKM

Pemerintah Provinsi Jawa Barat (2016). Smart City Perlu Payung Hukum. Retrieved July 18, 2019 from https://jabarprov.go.id/ index.php/news/19734/2016/10/27/ Smart-City-Perlu-Payung-Hukum

Prayudi, Y. (2018). UMKM Jadi Target Baru Pelaku Cybercrime. Retrieved January 22, 2019 from http://jogja.tribunnews. com/2016/05/22/umkm-jadi-target-barupelaku-cybercrime?page $=2$

Putra, A. H. (2016). Peran UMKM dalam Pembangunan dan Kesejahteraan Masyarakat Kabupaten Blora. Artikel Jurnal Analisa Sosiologi Oktober (Vol. 2016).

Putranti, I. R. (2015). Developing of Cyber Resilience System of the International Trade Facilitations: Specific reference Indonesia.

Razak, D. A., Abdullah, M. A., \& Ersoy, A. (2018). Small Medium Enterprises (SMES) in turkey and Malaysia a comparative discussion on issues and challenges. 15th Kuala Lumpur International Business Economics and Law Conference 2018 (KLIBEL 15), na(na), 1-12. Retrieved from http://irep.iium.edu.my/63627/

Rizkia, C. and Mahardy, D. (2018). Pemkot Semarang Gandeng Go-Jek dan Blibli.com Wujudkan Smart City. Retrieved January 
22, 2019 from https://technologue.id/ pemkot-semarang-gandeng-go-jek-danblibli-com-wujudkan-smart-city/amp/

Septiadarma, D. and Triwidodo, V. (2017) Workshop Digital Economy dan Smart City, Meningkatkan Kualitas UMKM e-Dagang. Retrieved January 22, 2019 from http:// koranmemo.com/workshop-digitaleconomy-dan-smart-city-meningkatkankualitas-umkm-e-dagang/

Setiaji, D. (2018) Apa Itu Smart City dan Tantangan Penerapannya di Indonesia. Retrieved January 21, 2019 from https:// id.techinasia.com/apa-itu-smart-city-danpenerapan-di-indonesia

Sindo News (2019). Tak Diatur dalam Perpres BSSN, Keamanan Siber Perlu Regulasi. Retrieved December 18, 2018 from https://nasional.sindonews.com/ $\mathrm{read} / 1271227 / 14 /$ tak-diatur-dalamperpres-bssn-keamanan-siber-perluregulasi-1515133241

Siaran Pres Kemenperin RI. (2018). Kemenperin: Menperin: Industri Kerajinan Berpotensi Sumbang Ekspor Besar. Retrieved January 21, 2019 from http:// www.kemenperin.go.id/artikel/19724/ Menperin:-Industri-Kerajinan-BerpotensiSumbang-Ekspor-Besar

Sismanto, A. (2016). Jumlah UMKM di Semarang Meningkat 1,97\% Tiap Tahun. Retrieved January 22, 2019 from https:// ekbis.sindonews.com/read/1095724/34/ jumlah-umkm-di-semarang-meningkat197-tiap-tahun-1458873873

Smart Cities Berkeley (2019) Smart Economy. Available at: Retrieved January 21, 2019 from https://smartcitiesberkeley. wordpress.com/2012/02/27/smarteconomy/

Stefanie, C. (2018) Jokowi Minta UKM Kerajinan Tangan Jadi Lebih 'Gaul'.
Retrieved January 22, 2019 from https://www.cnnindonesia.com/gayahidup/20170927143756-282-244367/ jokowi-minta-ukm-kerajinan-tangan-jadilebih-gaul

Tirto.id. (2019). UU ITE Dinilai Belum Cukup Lawan Kejahatan Siber. Retrieved December 20, 2019 from https://tirto. id/uu-ite-dinilai-belum-cukup-lawankejahatan-siber-dgqu

Tribun Jateng (2018) Dorong UMKM Semarang Bersaing di Pasar Nasional, Hendi Gaet Gojek dan Blibli - Tribun Jateng. Retrieved January 22, 2019 from http://jateng. tribunnews.com/2018/11/23/dorongumkm-semarang-bersaing-di-pasarnasional-hendi-gaet-gojek-dan-blibli

Wahid, I. (2017). Digitalisasi UMKM, Keniscayaan Era Modern - kumparan. com. Retrieved November 13, 2018, from https://kumparan.com/ipang-wahid/ digitalisasi-umkm-keniscayaan-eramodern

Walfajri, M. and Narita. (2018) Jumlah pelaku UMKM di 2018 diprediksi mencapai 58,97 juta orang. Retrieved January 22, 2019 from https://keuangan.kontan.co.id/ news/jumlah-pelaku-umkm-di-2018diprediksi-mencapai-5897-juta-orang

Yasa, A. (2018). Kemenkop UKM Catat 3259 UKM Gunakan Aplikasi Pembukuan Akuntansi. Retrieved November 16, 2018, from http://industri.bisnis.com/ $\mathrm{read} / 20180510 / 87 / 793746 /$ kemenkopukm-catat-3259-ukm-gunakan-aplikasipembukuan-akuntansi

Yuliana, O. (2004). Penggunaan Teknologi Internet dalam Bisnis. Jurnal Akuntansi dan Keuangan, 2(1), 36-52. https://doi. org/10.9744/JAK.2.1.PP. 36-52.Optasim quis nimpore stibustrum quosto temolorpos ad eos de laboraturi omnisEctisQuature. 